\title{
Cultural Route and Ecomuseum Concepts as a Synergy of Nature, Heritage and Community Oriented Sustainable Development Ecomuseum „Ibar Valley“ in Serbia
}

\author{
PhD Aleksandra Terzić ${ }^{1}$, PhD Željko Bjeljac ${ }^{1}$, \\ Msc Ana Jovičić ${ }^{1}$, Msc Ivana Penjišević ${ }^{1}$
}

\begin{abstract}
:
In tourism trends on global level became obvious the popularity of cultural tourism. There is a growing interest and connection between natural and cultural heritage with a living societies, with the growing concern for nature and heritage preservation. Importance of tourism and the role of cultural tourism are becoming of strategic importance in global economy, especially in underdeveloped countries. This study examine the successful management practices in creation of culture based tourism destinations and applying their practices to undeveloped regions. Study is using principles and practices that are in-line with "eco-museum", "cultural routes" and "cultural district" ideals, which break from traditional approaches to heritage management and tourism use. The aim is to highlight the synergies between common philosophy and promotion, safeguarding and conservation of heritage and enhancing the economic, social and cultural wellbeing of local communities. Theoretical base of study is focused on principles of tourism valorization method applied on heritage complexes, sustainability indicators of tourism development and a survey conducted on a focus group of tourism experts engaged in Ibar Valley in Serbia, that enabled the quantitative results of the evaluation process. The aim is to highlight the synergies between landscape, heritage and festivals (living culture), trough safeguarding and conservation of heritage resources and tourism promotion.
\end{abstract}

Keywords: culture, tourism, heritage, management, promotion

\section{Introduction}

Cultural and natural attractions in last two decades become a very important component in constituting the attractiveness of tourism destinations. As a result, a considerable number of tourist studies have been carried out in diverse cultural and 
natural geographic attractions (Craik, 1997, Moscardo, Pearce, 1999; Richards, 2000; Chhabra at all, 2003; Apostolakis, 2003; Timothy, 2007; Richards, 2007). „Culture as a tourist attraction can be a powerful force in arguing that a region's historic, cultural, religious and industrial past should be conserved" (Brokensha, Gruldberg, 1992; Harrison, 1997; McKercher, du Cros 2005). Heritage tourism reintroduces people to their cultural roots (Donert \& Light, 1996) and reinvigorates people's interest in history or culture. In latest world tourism trends became obvious the popularity of cultural tourism, as well as establishment of growing interest in connection between natural and cultural heritage with a living societies (Richards, 2000; Richards, 2007). Bearing in mind that tourism as the constituent part of total economic activities, insures prosperity of the place where developing by its economic effects, it is clear this economic activity should be analyzed and interpreted as one of the potential actuators of revitalizing of the areas, which have been characterized as undeveloped (Bjeljac, Ćurčić, 2008).

Based on global trend the number of cultural routes, cultural districts (Di Pietro, 2013) and eco-museums, in the world is growing. These culture based tourism products are different their themes, but bare the same principles in scope of heritage protection, tourism promotion and sustainable development. Some statistical data show that these specialized tourist products are attracting more and more tourists every year. These concepts were developed in Western Europe (Italy, France), considering that Europe has the richest cultural heritage and is the most visited destination of so called "cultural tourists". In South-Eastern Europe, most recently started the initiative for creating tourist destinations based on cultural heritage, and it was followed by creation of cultural routes and eco-museums. Introduction to these concepts motivated different public sectors and governmental institutions to start using the term "cultural routes", "ecomuseum" and "cultural path" in promoting the larger number of heritage sites archaeological, fortresses, castles, monasteries, museums and other. Within this framework, the South Eastern European region has a lot to contribute to the European and international tourism sector by further promoting a proper management of its UNESCO sites and linking them to the major cultural and natural tourism destination networks (Andrian, Stanojlović, 2011).

Case study is focused on application of several evaluation methods on cultural route/ecomuseum Ibar Valley in Serbia. Valley of the Ibar River in Serbia can be regarded as both, a cultural route and eco-museum. This area is particularly rich in heritage sites, including exceptional landscape and most representative historical monuments in Serbia. Parts of this Valley are included in the European cultural route "Transromanica" and more recently Ecomuseum "Ibar Valley" was established in this area as the first eco-museum in Serbia.

\section{Literature review}

Tourism and culture are recognized as two strong drivers of growth all around the world, especially in Europe, primarily through economic development and employment (Prentice, 1994; Hadžić, 2004). However, they have a crucial role in fostering understanding and preserving of richness and diversity of regional cultures, as well as greater valuation of a common heritage. Cultural attractions play an important 
role in tourism at all its levels, from global emblem of world culture to attractions that reflect the local cultural identity (Stanojlović et al., 2010). Cultural tourism has a number of goals that have to be achieved in accordance with the context of sustainable development, such as conservation of cultural resources, constant interpretation of resources, creation of authentic experiences among tourists, feedback stimulation for cultural resources and resident community. The cultural heritage and events in turn are seen as important tool for attracting visitors and building image within different communities (Raj, 2003).

More and more values-based approaches entered the domain of the traditional conservation science, bringing the evidence that the 'outstanding universal value' is not a static concept, but rather a vital and constantly changing one, largely depending on the ways heritage sites are experienced (Andrian, Stanojlovic, 2011). The alternative argument is that the sharing of the resource creates partnership opportunities, whereby mutually beneficial outcomes can be achieved through creation of cultural routes and ecomuseum that rely on sustainable development aspects.

Terms „cultural route“, „cultural path“ and „heritage trail“ are considered to be synonyms and define unique complex of connected assets of cultural heritage on determinate geographical area (Council of Europe, 2009). The key role in initiative for forming cultural routes in Europe had the working group of Council of Europe "Europe continues" ("L'Europe continue") in Paris, 1954, but the birth of the programme dedicated to European cultural routes is developed in Grenada, 1985. Council of Europe presented it as a way to share cultural heritage between several European countries, and gave an initiative for long-term multilateral projects of cooperation between cultural routes in neighboring countries (Mangion, Tamen, 1998). The concept is accepted by UNESCO's Committee of Cultural Heritage (Madrid, 1994), and defined as: „Route of heritage that is consisted of tangible elements in which the cultural importance comes from the exchange and multidimensional dialog between countries and regions, that illustrate the interaction of movement, along the route, in time and space" (UNESCO, 2004: 3).

The routes are considered to be the determinate way of travel that is usually consisted of the roads with significant landscape, cultural, historical, geological or natural values, and sightseeing sites is included in the scope of this route (Beau, 1998; Beck, Cable, 2002; Meyer, 2004; Stanojlović, et al., 2011). The basic concept is based on the connection of serial of tourism attractions with the goal of promoting tourism and encouraging tourists to travel from one to other location on some territory (Prentice, 2001; Richards, 2002, Hyounggon at all 2007). Cultural routes are highly valued mostly because of their identity, physical connection to the past and the continuity of their existence and use (ICOMOS-CIIC, 2004:3). The goals that would be achieved by creation of the route are attracting the visitors, networking between cultural destinations and resources, interpretation of cultural heritage, the engagement of local communities, protection and conservation of heritage, and promotion of the sustainable tourism development (Stanojlović, 2009; Stanojlović, et al., 2011).

Eco-musemum concept also originates from France, and the term 'ecomusée' is developed in 1971, even thou term "eco" is derived from "ecology" it refers especially to a new idea of holistic interpretation of cultural heritage, in opposition to the focus on specific items and objects, performed by traditional museums (Howard, 2002). An eco- 
museum is a type of open air museum that is focused on the identity of a place, largely based on local participation and aiming to enhance the welfare and development of local communities. "An eco-museum is a dynamic way in which communities preserve, interpret, and manage their heritage for sustainable development. An eco-museum is based on a community agreement" (Declaration of Intent of the Long Net Workshop, European Network of Eco museums, Trento, 2004) or according to Davis (2007:199) "a community-driven museum or heritage project that aids sustainable development".

Eco-museum principles have an emphasis on: self-representation; full community participation in, and ownership of, heritage resources and the management processes; rural or urban regeneration; sustainable development; and, responsible tourism (Boylan, 1992). Eco-museum principles have now been deployed in many countries throughout the world, and in a variety of ways, responding to local physical, economic, social, cultural and political environments in order to manage the full range of environmental and heritage resources through processes that encourage public participation.

In order to ensure the sustainable development of tourism at destination level, some principles must be ensured, which concern in particular the local community: decent livelihood opportunities (locals selling products to tourists or supplying stores, etc.); poverty incidences and alleviation in tourist areas; numbers of tourism businesses owned and operated by the locals; percentage of staff employed by tourism businesses from the local communities; gender equality in the employment esp. concerning the locals; local communities' share of profits from tourism; tourism income of the local, and the average percentage it takes among their total income; training for locals to acquire competence and skill for participating heritage conservation and heritage tourism; respect for local intellectual property as indicated by laws prohibiting the trading in these assets; local's accessibility to heritage as tourism resource and use of tourism facilities; local community participation in decision making relating to tourism development of heritage resource (involvement in the planning, research and decision-making process and community satisfaction with tourism practice and heritage conservation); percentage of leaders of heritage conservation and tourism from local community; resettlement and compensation from tourism; education opportunity of the local people (Xiang, Wall, 2005).

By legistative measures long term competitiveness and sustainability of tourism sector, streightened through multi-level cooperation, and local and regional benefit of ne investments in this region should be ensured. The partnership and rational planing of cultural tourism development is based on networking and cooperation between stakeholders in diffrent levels - governmental institutions, heritage protection, tourism buissness and local communities (de Rojas, Camarero, 2007).

However, Ibar Valley can represent both, cultural route and eco-museum. In its general appeal it can be regarded as a specific cultural route in the Valley of the Ibar River, consisted of several destinations and designed as a cumulative tourist product based on cultural and natural attractions. The exploration of cultural projects in Serbia (Ibar Valley in particular) should allow the insight of advantages of successful practices and current problems, but also to enable finding the ways of applying the best practices in order to improve heritage status and enlarge tourist visitation in the future. 


\section{Evaluation of tourism development potential - Ibar Valley, Serbia}

The territories which consist the defined cultural route/ecomuseum 'Ibar Valley' are located in south west part of Serbia on the eastern frontier of the Dinarian Alps and it is located less in the valley of rivers Ibar and Raška. Ibar Valley cultural route is spreading over the valley of the rivers Ibar and Raška, from Kraljevo southwards to below Novi Pazar, the medieval Serbian state was born. That is why some call it "The Valley of the Kings" while others call it "The Lilac Valley". The territory if Ibar River valley is quite spacious and it takes the territories of three municipalities: Kraljevo, Novi Pazar and Raška. In any event, this valley is home to some of the most valuable Serbian heritage sites. The heritage assets that are included in this cultural route are mainly aging from the medieval period. They are representing the historical beginnings of Serbian state.

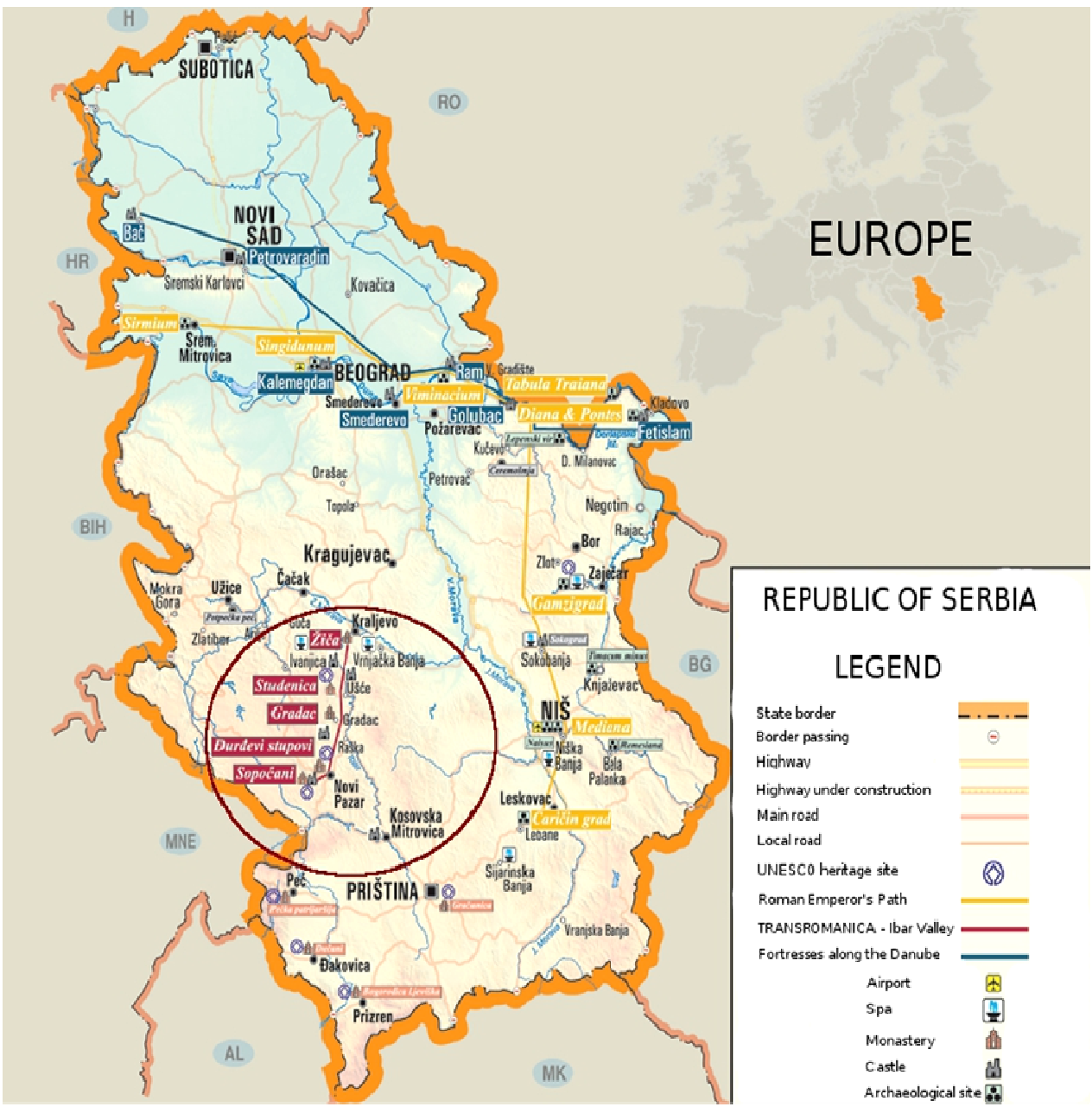




\section{Map 1. Geographical location and distribution of heritage resources in Ibar V alley}

During the history, from the antic times through the Roman and Byzantine period, thorough the phases of medieval and today in modern time, this area was always nested in the same historical and political space and context. In Roman period they were part of Roman province Mezia, medieval period was attributable with renaissances of Serbian medieval kingdom exactly in the Ibar valley (independent counties from $9^{\text {th }}$ century, and official Kingdom of Serbia from 1217 until 1459). In Ottoman period of role (1459 1804) Serbia was one territorial unit of the Empire. In modern times this territory is a part of so called Raška County whose administrative center is located in Kraljevo. This region is consisted of several urban centers as Kraljevo, Raška, Novi Pazar, Tutin and around 30 small towns and villages. It is a quite spacious territory; spreading around about $120 \mathrm{~km}$, but concentration and geographical, historical, and social cohesion of the particular point's legitimacy enables their networking in one cultural route system. The area has great potentials for tourism development but at the moment the development is in its first stages.

\subsection{Natural landscape and protected nature}

The beauty and diversity of natural landscape, as well as a level of preservation of natural and cultural assets in the Ibar Valley significantly contribute to the attractiveness of the areas. Here several protected nature parks are located. At the entrance of Ibar valley, south of Kraljevo, lie thermal spas - Mataruška spa and Jošanica spa, on the branches of mount Kopaonik declared for National Park. Nature Park Golija categorized as a natural asset of exceptional national importance, extending on the area of 75.184 ha in the First category of protection. It was also declared as UNESCO's MAB reserve Golija - Studenica $(53,804 \mathrm{ha})$ in 2001. The area of exceptional landscape Ras-Sopoćani in the Canyon of Raška River is an attractive natural complex with nature quality landscape, geomorphology phenomena and rare endemic species. Protected area is about 821 hectares large, with two zones of protection with II category of protection. There are also two Nature Reserves, Lojanik near Mataruška spa is a specific site with impressive geological character with fossil remains of silificated wood and special nature reserve Kamilje.

\subsection{Cultural heritage}

Cultural attractions, such as archaeological sites, medieval squares, castles and parks, as well as certain traditions and events are generally open public resources. However, with the increase in use, they tend to become public goods, preserved and maintained by the state. In order to assess how viable cultural tourism is in a particular situation, local communities should assess and evaluate their local situation and characteristics, including the exsistence of available tourist markets and the overall quality and integrity of the built and social environment, travel services and the prospect of potential markets. Community should not ignore local cultural elements such as museums, theaters, arts, events, crafts, gastronomy, historic and recreational areas, etc. Those cultural elements can be combined with elements of natural heritage to enrich and extend the stay of visitors. 
Heritage included in the creation of potential cultural route Ibar Valley in Serbia consists of two UNESCO sites - complex Stari Ras with Sopoćani monastery and monastery Studenica. Medieval castles are Stari Ras, Maglič, Novi Pazar, Brvenik and medieval monasteries are Žiča, Old and New Pavlica, Đurđevi Stupovi, Gradac, Crna Reka, Saint Sava Anchoress. Monasteries Žiča, Studenica, Gradac and Đurđevi Stupovi are included in the Major Cultural route of Council of Europe "Transromanica" recognized in 2007. Here some oriental monuments as Altun alem mosque, old Hamam in Novi Pazar and several mosques have a great value showing the historical and cultural influences of Muslims in this region.

\subsection{Cultural events}

The tradition of organizing festivals and events in Ibar valley in Serbia is old, and some events have tradition several centuries old. However, most events that are organized today in this region are more recently developed as an initiative of local governments as major hotspots for artists and tourist to enjoy multicultural events during the spring and summer months each year. The biggest and best known events from a bigger list of local events are Days of Liliac, Days of queen Helene of Anjou, Raška Spiritual Celebrations, Žiča Spiritual Convocation, Artistic collonies „Studenica“ and „Sopoćani visions“, sport events „Marry regata“ and Ibar-Morava regata.

\section{Ecomuseum „Ibar Valley"- the SeeNet project}

The initiative for tourist and cultural development of this region started with the project Ecomuseum Ibar Valley, starting from 2010. Ecomuseum Ibar Valley project was the part of wider SeeNet programme Enhancement of environmental tourism in the territories of Kraljevo (Serbia), Nis (Serbia), Nikšic (Montenegro), Peja - Pé́ (Kosovo and Metohija) and Shkoder (Albania). It focused on the development of environmental tourism routes in the Western Balkan Countries by the international cooperation of Trento with involved municipalities. The partnership between Comitato Servizi Cooperacione coi Balcani (Trento, Italy), city of Kraljevo and Local Association "Sodalis" (Kraljevo) was established.

The project intended to enhance the cultural and environmental resources in Ibar Valley and, consequently, create the tourism offer through the development of Eco-museum. The local community was expected to have a leading role in those actions. The project included three different fields of activity - the infrastructure interventions for the enhancement of the Maglic Castle in Kraljevo; the training of communities and tourism operators by introducing the models of the ecomuseum in cooperation with Italian education centres; and the promotion of territories and environmental tourism routes.

The goal of this project was the improvement of capacity of local government for managing the active policy in sustainable development of the area and the support to the sustainable tourism development through the management and protection of natural and cultural heritage. Particular attention is given to the rising of the awarenes $s$ of local communities about the cultural and environmental heritage of their territories (www.seenet.org). 
This initiative was followed up with the creation of tourist publication "Ecomuseum The Valley of the Ibar River" and the pilot project for development of tourist center "Kraljev grad" by Tourist organization of Kraljevo, as well as promoting the event "Fortresses Regata" by NGO "Spust bez. granica-Raška".

\section{Methodology}

Within the activities conducted within SEENET II (A trans-local network for the cooperation between Italy and South-Eastern Europe) project "Ecomuseum Ibar Valley", in period 2011-2013, the internal survey among experts in tourism and heritage management was conducted. Within this survey the general attitude towards tourism development, the current state of destination management and cultural heritage in the region is measured. According to the results the estimation of potential for the development of cultural tourism offer in this region was obtained. Theoretical base of study is focused on principles of Hilary du Cros tourism valorization method applied on heritage complexes in order to determinate the current state and a potential of heritage site for tourist use in a sustainable way. Moreover, the evaluation of sustainable tourism development indicators defined by Xiang and Wall (2005) was used in order to determine the level of sustainability aspects achieved in this region.

During tourist evaluation of heritage properties, complex Hilary du Cros model has been applied (du Cros, 2000; du Cros, 2001; Hadžić, 2005), which values two basic sectors tourist sector and sector of heritage management, through line of cultural and touristic sub-indicators. For every analyzed sub-indicator, a valuation scale has been founded, whereas scoring has been conducted numerically (Table 1). Based on conducted valuation, „matrix of market appeal/robustness” has been set up and later on, belonging to one of the cells of the matrix has been determined for each resource and properties, depending on its score within scoring process (Bjeljac, Ćurčić, 2008). Matrix has nine cells, marked with $M(i, j)(i, j=1,2,3)$ and for each resource is determined to which cell it belongs, based on the values given in the previous evaluation process (Hadžić, 2005; Besermenji, et al., 2008). During the creation of tourism product, the visitation aspect to cultural resource should be foreseen, for cultural resource marked with cells $M(2,3)$ and $M(1,3)$.

The evaluation of sustainable tourism development indicators defined by Xiang and Wall (2005) was used in order to determine the level of sustainability aspects achieved in this region durring the application of Ecomuseum concept in Ibar Valley. Indicators defined that include sustainability aspects of development within three categories are established (Table 2). These indicators were used in a form of questions in a survey process. The final assessment of sustainable cultural tourism development is made on the basis of having a set of indicators on three levels - Sustainability of heritage resources, Sustainability of tourism and Sustainability of local community, with great number of sub-indicators in order to determine to which level of sustainability they belong. Average mark is calculated for each indicator, based on estimation of set of subindicators. According to general score, development sustainability is defined as Low 10 - 25, Medium 26-40, High 41-50.

Moreover, the survey on heritage attractiveness of the Ecomuseum Ibar Valley was conducted among the event visitors in 2012. It shows the quality aspects and estimates the potentials for tourism development in this area. 


\section{Results}

With a goal to show the role that cultural events and cultural heritage have in attracting the tourist and the development of cultural tourist destination, the questionary based research was conducted among the visitors of several larger cultural events in this are - Days of Liliac, Days of Helene of Anjou and Raska Spiritual Celebrations. The results of the completed research shown that most of the visitors were locals and domestic tourists from surrounding regions. The respondent (120 people) structure was equaly distributed among gendre (45\% male and 55\% female) and age (young (up to 29) - 21\%, adult $(26-60)-48 \%$ and elders (over 61) - 31\%)). Educational level (ellementary $-15 \%$, highschool $-42.2 \%$, university $-42 \%$ ) and standards of living (low $-28,9 \%$, average $-55,5$ and high $-8,8 \%$ ) were consistent to the Republics average. About $64.5 \%$ of respondents planned to visit heritage sites in the Ibar Valley durring and after the event. The considerable number of visitors was satisfyed with the quality of the heritage resources and event programms in this region. Over $75 \%$ of the respondents declared their will to visit the Ibar Valley again and will recomend it to their frends and familly. On the other hand, the respondents pointed out some issues that demand the improvement - higher invovement of local communities $(5,7 \%)$, repairment and reconstruction of the sacral places $(4,4 \%)$, improvement of the infrastructure $(8,9 \%)$, improvement of management aspects $(8,8 \%)$, more marketing and promotion $(13,4 \%)$, etc.

The evaluation of sustainability indicators is based on panel discussion (focus group) and survey of 12 experts (tourism organizations, Museums, Heritage protection centers, NGOs, local community representatives). Lists of indicators are evaluated by respondents with application of the Likert scale (15), with mark 1 defining the worst situation (strong disagreement) and mark 5 defining the best situation (full agreement), considering the standards defined by experts perceptions.

Table 1. Evaluation of sustainability aspects of the tourism development, Ibar Valley, Serbia

\begin{tabular}{|c|c|c|c|}
\hline \multirow{10}{*}{$\begin{array}{l}\text { Tourism } \\
\text { appeal }\end{array}$} & H. du Cros sustainable development indicators & Results & Scale \\
\hline & Ambiance (natural/cultural) & 4,3 & $0-5$ \\
\hline & Well-known outside local area & 3,5 & $0-5$ \\
\hline & Significant national symbol & 3 & $0-5$ \\
\hline & Can tell an "interesting" story & 4,1 & $0-5$ \\
\hline & Clearly distinguished from nearby assets or attractions & 3,6 & $0-5$ \\
\hline & Appeals to special needs & 2,6 & $0-5$ \\
\hline & Complements other tourism products in the area & 4,6 & $0-5$ \\
\hline & Tourism activity in the region & 2,7 & $0-5$ \\
\hline & Destination associated with culture & 3,9 & $0-5$ \\
\hline \multirow{4}{*}{$\begin{array}{l}\text { Product } \\
\text { design }\end{array}$} & Accessibility & 2,6 & $0-3$ \\
\hline & Transport possibilities & 1,9 & $0-3$ \\
\hline & Number of attractive natural/cultural attractions nearby & 2,7 & $0-4$ \\
\hline & Services availability & 1,9 & $0-5$ \\
\hline \multicolumn{2}{|c|}{ Tourism attractiveness score } & 41,4 & 60 \\
\hline
\end{tabular}




\begin{tabular}{|c|c|c|c|}
\hline \multirow{5}{*}{$\begin{array}{l}\text { Cultural } \\
\text { value }\end{array}$} & H. du Cros sustainable development indicators (continued) & Results & Scale \\
\hline & Aesthetic value & 1,7 & $0-2$ \\
\hline & Historical value & 1,8 & $0-2$ \\
\hline & Educational value & 1,8 & $0-2$ \\
\hline & Social value & 1,7 & $0-2$ \\
\hline \multirow{11}{*}{$\begin{array}{l}\text { Heritage } \\
\text { management }\end{array}$} & Scientific potential/Research & 1,5 & $0-2$ \\
\hline & Rareness in the region & 2,5 & $0-5$ \\
\hline & Representativeness & 3,1 & $0-5$ \\
\hline & Fragility & 3,5 & $0-5$ \\
\hline & Current state & 3,3 & $0-5$ \\
\hline & Management plan & 3,2 & $0-5$ \\
\hline & Regular monitoring and maintenance & 2,9 & $0-5$ \\
\hline & Possibility of negative impacts of high visitation numbers & 3,5 & $0-5$ \\
\hline & Possibility of negative impacts of modification & 2,6 & $0-5$ \\
\hline & Potential for involvement and consultation of key stakeholders & 2,6 & $0-5$ \\
\hline & Investment potential & 3,4 & $0-5$ \\
\hline \multicolumn{2}{|c|}{ Heritage management score } & 39,1 & 60 \\
\hline
\end{tabular}

According to the results of the research shown in Table 1 the result of the evaluation of heritage resource suitability for tourism development, Ibar Valley is marked as $M(1,2)$, which is a good result. Resources are evaluated to have high or medium value of cultural importance/robustness and medium market attractiveness. It must be noted that the result shown in Figure 1 is reflecting the current state of the cultural route/ eco-museum heritage assets and the value ratio can change in the future.

Figure 1. Evaluation of cultural route Ibar V alley in Serbia

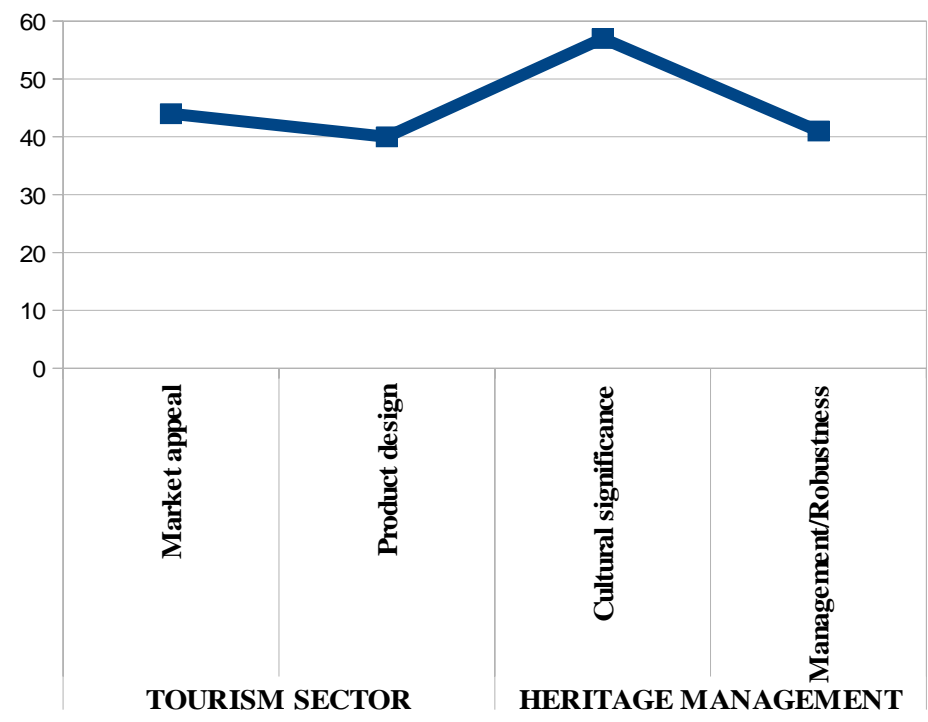

Figure 2 shows that certain cultural assets in the Ibar Valley posses' great potentials for tourism development, especially in regard to their cultural value and market appeal. Such resources contribute to 
the high attractiveness of the Ibar Valley - monasteries Žica, Sopociani and Studenica, Maglic castle, cultural events Days of Liliac and Days of queen Helen of Anjou, as well as natural assets such as Mataruške and Jošanica spas and natural park Golija. The highest results were achieved in the cultural significance aspect of the assets evaluated.

Figure 2. Evaluation of individual tourist attractions in Ibar Valley, Serbia

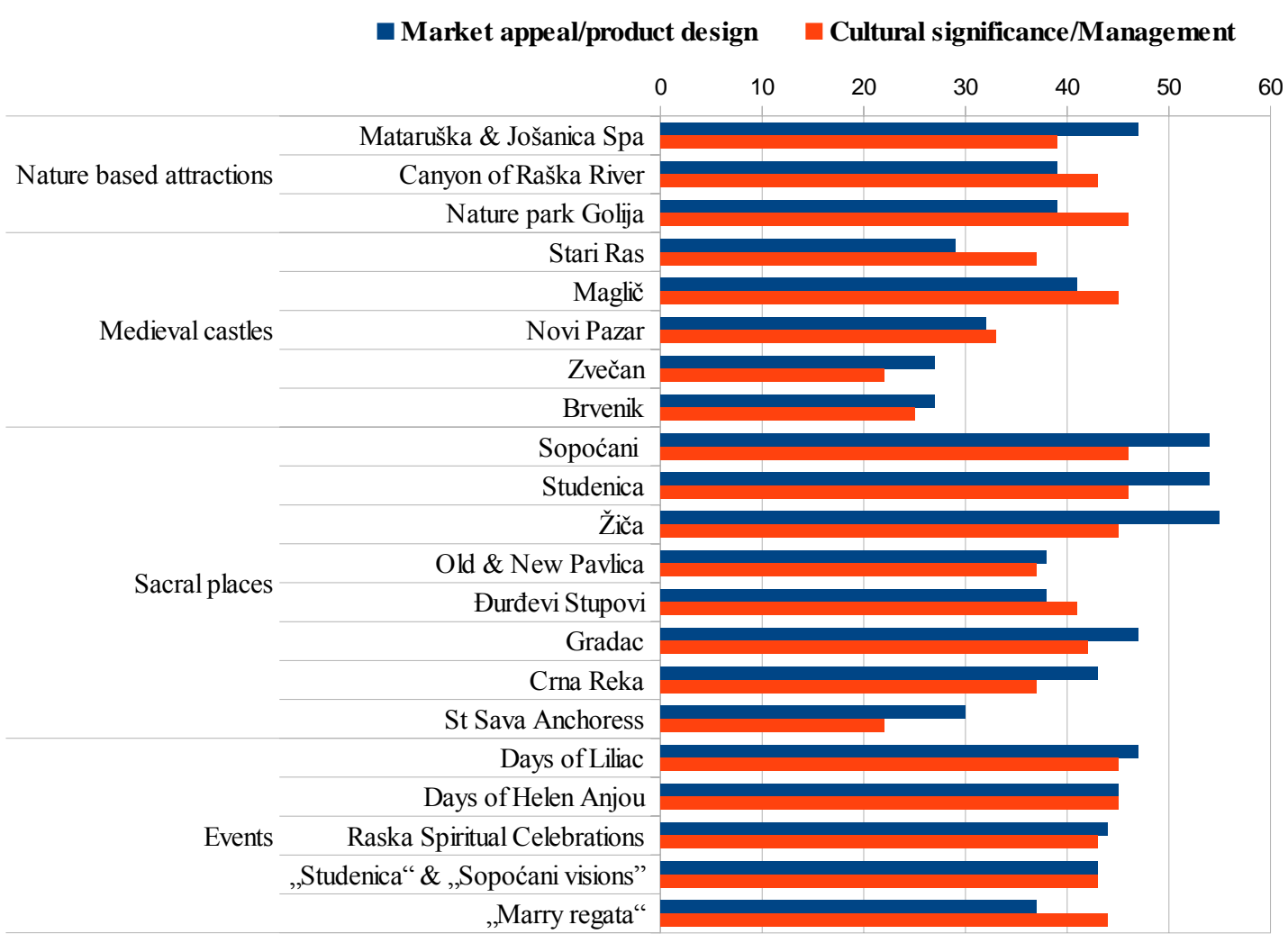

According to the assessment of the sustainability aspects of the development process in the Ibar Valley (Table 2), bighest results were recorded in the tourism sector (quality of visitor experience with average 34.6). 
Table 2. Assessment of sustainable tourism development in Ibar V alley

\begin{tabular}{|c|c|c|c|}
\hline STAINABII & ITY & Results & Scale \\
\hline Sustainability & resource integration and authenticity & 3,5 & $1-5$ \\
\hline $\begin{array}{l}\text { of heritage } \\
\text { resource }\end{array}$ & $\begin{array}{l}\text { condition of existing cultural and natural heritage } \\
\text { resource }\end{array}$ & 3,4 & $1-5$ \\
\hline conservation & condition of the resource environment & 3 & $1-5$ \\
\hline & laws and institutional guarantee for conservation & 3,6 & $1-5$ \\
\hline & respect for local heritage and intellectual property & 3 & $1-5$ \\
\hline & participation of local communities in conservation & 2,2 & $1-5$ \\
\hline & resource and environmental education & 2,4 & $1-5$ \\
\hline & monitoring mechanism & 2,6 & $1-5$ \\
\hline & defined jurisdiction and management system & 2,4 & $1-5$ \\
\hline & share of tourism revenue to finance conservation & 2 & $1-5$ \\
\hline Total & & 28,1 & 50 \\
\hline Sustainability & development of competitive quality tourism products & 2,9 & $1-5$ \\
\hline tourism & information availability for tourists & 3,4 & $1-5$ \\
\hline (quality visitor & quality of guides and interpretations & 2,6 & $1-5$ \\
\hline & tourist purchase of local commodity & 3,6 & $1-5$ \\
\hline & frequency of tourist-local interactions and attitudes & 3,9 & $1-5$ \\
\hline & tourist perception of the authenticity & 3,9 & $1-5$ \\
\hline & safety for tourists & 4,4 & $1-5$ \\
\hline & extent of use of transport & 3,1 & $1-5$ \\
\hline & method of waste disposal & 3 & $1-5$ \\
\hline & architecture style and material used for building. & 3,9 & $1-5$ \\
\hline Total & & 34,6 & 50 \\
\hline Sustainability & decent livelihood opportunities & 3 & $1-5$ \\
\hline local & poverty incidences and alleviation in tourist areas & 3,3 & $1-5$ \\
\hline community & number of tourism businesses owned by the locals & 3,7 & $1-5$ \\
\hline (tourism- & percentage of locals employed by tourism businesses & 2,9 & $1-5$ \\
\hline & local communities' share of profits from tourism & 2,6 & $1-5$ \\
\hline & $\begin{array}{l}\text { training locals to acquire competence in heritage } \\
\text { conservation and tourism }\end{array}$ & 1,8 & $1-5$ \\
\hline & local's accessibility to heritage and tourism facilities & 3,3 & $1-5$ \\
\hline & local community participation in decision making & 2,1 & $1-5$ \\
\hline & in relevance to the tourism development & & $1-5$ \\
\hline & resettlement and compensation & 1,9 & $1-5$ \\
\hline & education opportunity of the local people. & 1,2 & $1-5$ \\
\hline Total & & 25,8 & 50 \\
\hline & ang and Wall (2005) & & \\
\hline
\end{tabular}

On the other hand, aspects that consider sustainability of the local community (tourism related) and heritage resource management are relatively low (average 29.5 and 28.4 of 50 points) (Figure 3). 
Figure 3. Sustainability assessment of Ecomuseum Ibar V alley, Serbia

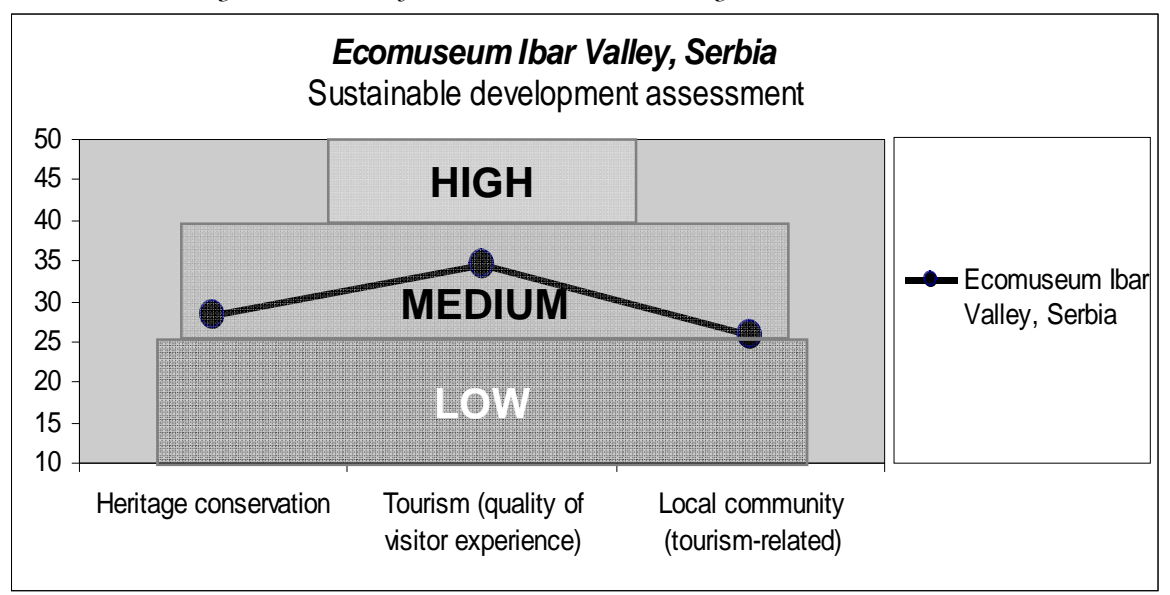

The current results of the study are mostly the result of the long history of bad practices in heritage management and protection, as Serbia is country with small amount of knowledge and technological approaches in the area of heritage management, compared to other European countries. Heritage and nature based resouces in Serbia have experienced a long period of negative tendencies in the relation to the preservation and management, which is the main reason for the poor state of the most of valuable heritage sites (Stanojlovic et al., 2011). The main problems concern the generally low levels of management and lack of quality product design (bad quality of infrastructure, interpretation and investments in the area) followed by non-existence of management plans and local initiatives, that are generally present in Serbia. Generaly the local communities have small amount of initiative and quite often play only marginal role in the tourism development process. According to attractiveness of the heritage resources in the Ibar V alley, after the evaluation process, gained relatively high value rank, with observed realistic potentials for quality tourism product design.

However, these resources should be monitored by conservators and managers with goal of sustainable tourism development, management plan should be developed and goals defined. Local community involvement and direct benefits should be ensured. Cultural assets should be promoted on proper manner, on national and international levels. After achieving these goals, it is expected that the tourist product Ecomuseum "Ibar Valley" become the leading cultural tourist offer in Serbia. The initiative for the change towards sustainable development of the country raised the awareness for the protection of natural and cultural heritage, and with the help from international organizations and institutions as UNESCO, Council of Europe and many others, the things are slightly getting better. It can be expected that in the future, the heritage in Serbia will be maintained and used in the proper way for cultural, social and tourism purposes. 


\section{Conclusion}

Creation of cultural routes and eco-museums, as they share the same vision of sustainability and protection of the heritage, is considered to be the proper method for achieving the sustainable development. The valorization of all the resources that are included in that route is a key action in order to perceive the real potentials of the resources and all the elements needed to evaluate their value, protection and management actions in order to develop destinations and design sustainable tourism products. According to the results of the evaluation of sustainable development of Ecomuseum Ibar Valley, it is concluded that it followed the cultural route and ecomuseum concepts of development.

Ibar Valley proved to be much more successful in the management and protection issues, as well as the product design issues, by achieving relatively high results, compared to other similar tourist destinations in Serbia. However, Ibar Valley is still undeveloped space, that in recent years it shows some higher prospects for tourism development. Most of the activities on tourism development is undertaken trough the numerous projects of several civil organizations, either local or international. Evaluation methods applied in this study showed the missing parts in the development of this route, and pointed what actions should be undertaken in order to improve the current state. Considering the current state of Serbia as a transitional country and long history of inappropriate heritage management and low finances in this sector, the support on international level is needed. Most offten it is practice to wait for international institutions, for example, UNESCO and Council of Europe, to undertake more initiatves for protection and management of cultural resources in Serbia, esspecially in educational aspect.

More public funds and organizations that take actions in heritage protection and management should be developed, and the public should be learned in the specific ways to care and protect their heritage. In order to keep valuable heritage for the future, all the cultural, educational and tourism-related institutions that operate in this sector should be engaged. Tourism development is considered to be the right way for improving the state of heritage, protection, regeneration and presentation of heritage to a wider public. It also should enable gaining some financial income for local communities in order to achieve its further development and proper management, in terms of sustainability.

Acknowledgement: This research is a part of project "Geography of Serbia", N: III 47007, financed by Ministry of Education and Science of Republic of Serbia.

\section{References}

Andrian, G., Stanojlović, A. The role of the UNESCO designated sites (World Heritage Sites and Biosphere Reserves) in fostering sustainable tourism in South-East Europe. SEE conference, Opatija, Croatia, 2011.

Apostolakis, A. (2003) The convergence process in heritage tourism. Annals of Tourism Research, Vol. 30 (4), pp. 795-812.

Beau, J.F. (1998): Dossier les routes touristiques. Decision Tourism, No. 29, April 1998. 
Beck, L., \& Cable, T. (2002): Interpretation for the 21st Century. Fifteen Guiding Priciples for Interpreting Nature and Culture. Champaign: Sagamore Publishing.

Besermenji, S., Pivac, T \& Jurisin I. (2008). Tourist significance of Galery „Milan Konjovic:” in Sombor Journal of Geographical institute „Jovan Cvijic“, SASA, Belgrade, Vol. 58, pp. 87-104 (in Serbian)

Bjeljac, Ž. \& Čurčić, N. (2008) Tourism valorization of harvest manifestations in Serbia. Collection of papers of Faculty of Geography, Belgrade, Vol. 56, pp. 177-192. (in Serbian)

Boylan, P. (1992) Ecomuseums and the new museology - some definitions. Museums Journal, Vol. 92 (4), p. 29.

Bowitz, E., Ibenholt, K. (2009) Economic impacts of cultural heritage - Research and perspectives. Journal of cultural heritage, Vol. 10, pp. $1-8$.

Chhabra, D., Healy, R., \& Sills, E. (2003) Staged authenticity and heritage tourism. Annals of Tourism Research, Vol. 30(3), 702-719.

Craik, J. (1997) The culture of tourism. In C. Rojek, \& J. Urry (Eds.), Touring cultures: Transformations of travel and theory, London: Routledge, pp. 114-136.

Choi, S., Ritchie B.W, Papandrea F, J. Bennett (2010) Economic valuation of cultural heritage sites: A choice modeling approach. Tourism Management, 31, pp. 213-220

De Rojas, C., Camarero, C. (2008). Visitors' experience, mood and satisfaction in a heritage context: Evidence from an interpretation center. Tourism Management, vol. 29 525-537.

Di Pietro, L., Mungion, R. G., Renæi, M.F. (2013) Cultural technology district: a model for local and regional development, Current Issues in tourism, Vol. 16, Issue 1, pages 1-17.Harrison, J. (1997) Museums and touristic expectations. Annals of Tourism Research, Vol. 24(1), pp. 23-40.

Donert, K., \& Light, D. (1996) Capitalizing on location and heritage: Tourism and economic reorganization. In Argentiere La Basse, High French Alps. In L. Harrison, \& W. Husbands (Eds.), Practicing responsible tourism, Brisbane: Wiley, pp. 193-215.

Du Cros H. (2000) Planing for sustainable Cultural Heritage Tourism in Hong Kong. Final report to the Lord Wilson Heritage Trust Council, SAR

Du Cros, H. (2001) A new model to assist in planning for sustainable cultural heritage tourism. International Journal of Tourism Research, Vol. 3, pp. 165-170.

Hadzic, O., Stojakovic, G., Herman-Milenkovic, K., Vanic, T., Ivanovic, I. (2005) Cultural tourism. Faculty of Science, Department of geography, tourism and hotel management, Novi Sad, Serbia (www.heritage.gov.rs)

Howard, P. (2002) The Eco museum: innovation and risks in future. International Journal of Heritage Studies, Vol. 8, issue 1, pp. $63-72$.

Hyounggon K, Chia-Kuen C, Joseph T. O'L (2007) Understanding participation patterns and trends in tourism cultural attractions. Tourism Management, Vol. 28, pp. 1366-1371.

Mangion, T., Tamen, I. (1998):European Cultural routes. Council Of Europe, Strasbourg.

McKerchera, P., Cross, du H. (2005) Relationship between tourism and cultural heritage management: evidence from Hong Kong. Tourism Management, Vol. 26, pp. 539-548.

Meyer, D. (2004): Tourism routes and gateways: Examples and a selection of key isues for development of tourism routes and gateways and their potential for pro-poor tourism. Tourism. London: ODI. (www. pppilot.org.za)

Moscardo, G., \& Pearce, P. L. (1999) Understanding ethnic tourists. Annals of Tourism Research, Vol. 26(2), pp. 416-434.

Prentice, R. (1994): Heritage: A key sector of the „new, tourism. IN C.P.Cooper \& A. Lokwood (Eds), Progress in tourism, recreation and hospitality management, Vol.5 (pp.309 324).Chichester: Wiley. 
Raj, R. (2003) The Impact of Festivals on Cultural Tourism. The 2nd DeHaan Tourism Management Conference "Developing Cultural Tourism", Nottingham, UK, December 16 th 2003.

Richards, G. (2000): World culture and heritage and tourism. Tourism Recreation Research, 25 (1), 9-18.

Richards, G. (2007, ed.): Cultural Tourism: Global and local perspectives. New York: Haworth Press.

Stanojlovic, A., Curcic, N., Pavlovic, N. (2010) Tourism valorisation of site "Lazar's town" in Krusevac. Journal of the Geographical Insitute "Jovan Cvijic", SASA, Vol. 60, number 2, pp. 77-92.

Stanojlovic, A., Lukic, T., Curcic, N. (2011) The initiative for cultural tourism development in Serbia Cultural route "Fortresses along the Danube". 2H2S Consortium European de Recherché en sciences bumaines et sociales "L'invention de nouveaux territoires en Val de Loire, Comparaisons Europeennes", July 2011, Angers, France.

Timothy, D. (2007): Managing Heritage and Cultural Tourism Resources. Critical Essays, Volume One. Cornwall: Ashgate.

Xiang, Y. and Wall, G. (2005). Heritage conservation and local communities: Pressing issues in the developing countries. In the proceedings of the 3rd Sino-Korea International Tourism Conference, Aug, 2005, Weihai, China.

European Commission - Using Natural and Cultural Heritage for the Development of sustainable Tourism in Non-Traditional Tourism Destinations, European Commission 2002. (http://ec.europa.eu/enterprise/services/tourism/studies heritage.htm)

ICOMOS Ename Charter for the Interpretation of Cultural Heritage Sites. http://hgk.biznet.hr/hgk/ fileovi/5675.doc

ICOMOS International Cultural Tourismus Charter.(http://hgk.biznet.hr/hgk/fileovi/5674.pdf)

ICOMOS International Scientific Committee on Cultural Routes (CIIC) - Report 2004 (www.icomos-ciic.org)

SEENET (http://www.see-net.org/index.php)

UNESCO (http://whc.unesco.org/archive/ routes $94 . h t m)$.

UNESCO Universal declaration on diversity. (http://unesdoc.unesco.org/images/0012/001271/127160m.pdf) 